\author{
Research Article \\ www.ijrap.net
}

\title{
ASSESSMENT OF GROWTH AND DEVELOPMENT IN INFANTS WITH SHASHTIKSHALYADI CHURNA AS WEANING FOOD: A CLINICAL STUDY
}

Sharvari S Deshpande ${ }^{1}$, Shailaja $\mathrm{U}^{2}$, Arun Raj GR ${ }^{1 *}$, Arya $\mathrm{TU}^{1}$

${ }^{1}$ PG Scholar, Department of PG Studies in Kaumarabhritya, SDM College of Ayurveda and Hospital, Hassan, Karnataka, India

${ }^{2}$ Professor, Department of PG Studies in Kaumarabhritya, SDM College of Ayurveda and Hospital, Hassan, Karnataka, India

Received on: 04/05/14 Revised on: 23/07/14 Accepted on: 02/08/14

*Corresponding author

Dr Arun Raj GR, Final year Post graduate scholar, Department of Kaumarabhritya, SDM College of Ayurveda and Hospital, Hassan - 573201, Karnataka, India E-mail: drdrarunraj26@gmail.com

DOI: $10.7897 / 2277-4343.05490$

\section{ABSTRACT}

The aim of this study was to assess the effect of Shashtikashalyadi Churna as weaning food on growth and development of infants. Infants were selected from outpatient department of SDM College of Ayurveda and Hospital, Hassan, Karnataka, India. Apparently healthy infants of weaning period were selected. Study and control group each containing twenty infants were included in the study. Shastikashalyadi weaning powder was given orally in dosage of $15 \mathrm{~g}$ twice daily besides breast milk. Along with breast milk, home-made mashed food was advised. Infants were assessed from age of six months till the age of nine months in various aspects of growth and development. Infants showed improvement in all aspects of growth. Weight gain in treated group was $27 \%$ (22\% in control group), height gain was $5.10 \%$ (6.76\% in control group) and chest circumference gain was $5.52 \%$ (5.5\% in control group). There was statistically significant improvement in reduction of attack of disease and sleep pattern. Nutritional supplement Shashtikashalyadi Churna was found effective in accelerating growth and development during weaning period and it helped in preventing growth faltering.

Keywords: Shashtikashalyadi churna, growth and development, weaning food, breast milk.

\section{INTRODUCTION}

Breastfeeding alone is sufficient for first six months of life, thereafter concentrated energy dense complementary foods are essential in order to maintain an adequate velocity of growth for the infant. ${ }^{1}$ Weaning is defined as the process of progressive transfer of the baby from breast milk to usual family or adult diet. Ayurvedic classics has mentioned the introduction of semisolid food as Annaprashana samskara (ceremonial initiation of complementary feeding). ${ }^{2-4}$ The World health organization defines complementary food as any food whether manufactured or locally prepared, suitable as a complement to breast milk or to infant formula, when either become insufficient to satisfy then nutritional requirements of the infant. Such food is also commonly called weaning food or breast-milk supplement. ${ }^{5}$ Weaning foods must be with desirable qualities like high in energy, easy to digest, low in bulk and viscosity and easy to prepare. ${ }^{6}$ Establishing of appropriate and quality weaning foods that assist in motor skills and motor development is important. $^{7}$ There is a need for complementary foods which are with optimum nutritional value and also economically sustainable. The cereals form the important part of diet in various parts of India. They form an important source of energy, iron, protein, in the Indian diet and also supply certain amount of fat. ${ }^{8}$ Hence the preparation with Shashtika Shali (a variety of rice which is harvested in 60 days) and other drugs like Godhuma (wheat), Yava (barley), Vidanga (Embelia ribes Burm.f.) in churna (powder) form (along with advised diet and breast milk) as mentioned by Acharya Kashyapa has been selected. ${ }^{9}$

\section{MATERIALS AND METHODS \\ Objective of the study}

To assess the effect of Shashtikashalyadi Churna as weaning food on growth and development of infants

\section{Source of data}

Infants were randomly selected from the outpatient department of SDM College of Ayurveda and Hospital, Hassan, Karnataka, India. Ethical clearance was obtained from Institutional Ethic committee of SDM College of Ayurveda and Hospital, Hassan, Karnataka, India (IEC No. SDMAH/IEC/59/11-12 dated 01-04-2012).

\section{Methods of Collection of Data Inclusion Criteria}

Infants between the age group of 6 to 9 months in whom weaning has not been started yet were included in the study.

\section{Exclusion Criteria}

- Infants of Premature birth

- Infants having malnutrition disorders like Protein energy malnutrition, Marasmus, etc.

- Infants having congenital disorders like cleft palate, etc.

- Infants suffering from systemic diseases like tuberculosis etc.

- Infants having CNS disorders like cerebral palsy, mental retardation, congenital diseases.

\section{Securing of Drugs}

Shashtika Shali, Godhuma and Yava were purchased from local market of Hassan, Karnataka, India. Vidanga 
(Embelia ribes Burm.f.) Churna, Jatiphala (Myristica fragrans Houtt.) Churna and Ela (Elettaria cardamomum Maton.) Churna were procured from SDM Ayurveda pharmacy, Hassan, Karnataka, India. The drugs were identified from department of Dravyaguna, SDM College of Ayurveda, Hassan, Karnataka, India.

\section{Research Design}

40 infants between the age group of 6-9 months who were attending the outpatient department of Kaumarabhritya of SDM College of Ayurveda and Hospital, Hassan, Karnataka, India, living in and around Hassan city, Karnataka, India and who were to be put to weaning were selected randomly and were taken up for the study after following the criteria laid as above. These 40 infants were divided randomly in to two groups:

1. Group A - Study group - containing 20 infants.

2. Group B - Control group - containing 20 infants.

Out of a total number of 40 infants taken for the study, three dropped out in the middle and did not continue treatment in the study group. While out of 20 in control group, 4 dropped out. Complete history and clinical examination of all these infants was carried out and recorded in a specially designed proforma by the postgraduate department of Kaumarabhritya of SDM College of Ayurveda and Hospital, Hassan, Karnataka, India.

\section{Assessment Criteria}

The infants who were included into the study were assessed before, during and after the study about the following growth and development parameters using Trivandrum screening chart. ${ }^{10}$

\section{Preparation of the trial drug}

The cereal grains were soaked in water over night (2-3 times its volume of water). The moist swollen grains were germinated in a moist dark environment covered with a cloth for 2 days. After sprouts were formed, they were shade dried for half day. The grains were slightly roasted in pan to remove excess moisture. The sprouts were removed and given for milling. Rest drugs like Jatiphala, Ela (Elettaria cardamomum (L.) Maton), Vidanga churna were obtained from teaching pharmacy, SDM College of Ayurveda and Hospital, Hassan, Karnataka, India and were evenly mixed to form homogenous mixture. The prepared food was packed in airtight container weighing $250 \mathrm{~g}$.

\section{Mode of Administration of supplementation}

- Study group: Shashtikashalyadi Churna was given 15 g twice daily. Shashtikashalyadi churna was mixed with water and boiled for 20 minutes till it attains semi-solid consistency and later added with cow's ghee and 1 table spoon of sugar to make it energy dense. Along with this, breast milk feeding was advised to continue.

- Control group: Along with breast milk, home-made mashed food was advised.

\section{Follow up Study}

After completion of the study, the parents and their infants were asked to attend the outpatient department once in a month for one month to know whether the improvement provided by the weaning powder is sustained.

\section{Observations}

20 patients were male whereas the other 20 were female. All the subjects were from Hindu community. Birth order wise distribution showed that 24 were of first order while 16 were of order second. Month wise distribution showed that 7 subjects were of age 6 months, 17 were of 7 month, 9 were of 8 month and 7 were of 9 month. All the subjects were vaccinated as per age. All were delivered at hospital setting only. Mode of delivery wise distribution showed that 26 subjects were of normal delivery while the remaining 16 were by LSCS. 35 subjects were part of nuclear family while the rest 5 were of joint family. Breast feeding after delivery wise distribution showed that 34 subjects were breast fed within 2-4 hours after delivery while the remaining 6 were breast fed after 2-3 days. 35 subjects attained neck holding at $3^{\text {rd }}$ month, 3 attained at 3.5 months while 2 subjects attained it at $4^{\text {th }}$ month. 36 subjects attained roll over at $5^{\text {th }}$ month, 3 attained at 5.5 months while 1 subject attained it at $6^{\text {th }}$ month. 2 subjects attained sitting with support at $5^{\text {th }}$ month, 29 attained at $6^{\text {th }}$ month, 2 attained at 6.5 months while 1 subject attained it at $7^{\text {th }}$ month. 3 subjects attained sitting without support at $7^{\text {th }}$ month while 9 subjects attained it at $8^{\text {th }}$ month. 33 subjects attained crawling on belly at $8^{\text {th }}$ month while 7 subjects attained it at $9^{\text {th }}$ month. 5 subjects' attained transfers objects hand to hand at $6^{\text {th }}$ month, 22 attained at $7^{\text {th }}$ month while 6 subjects attained it at $8^{\text {th }}$ month. 36 subjects attained pincer grasp at $9^{\text {th }}$ month while 4 subjects attained it at $10^{\text {th }}$ month. 3 subjects attained smiles at mirror image at $4^{\text {th }}$ month, 4 attained at $5^{\text {th }}$ month while 33 subjects attained it at $6^{\text {th }}$ month. 36 subjects attained babbles at $6^{\text {th }}$ month while 3 subjects attained it at $7^{\text {th }}$ month. 34 subjects attained imitate sound at $9^{\text {th }}$ month while 6 subjects attained it at $10^{\text {th }}$ month.

\section{RESULTS}

The initial mean weight of the infants in the study group before starting the weaning food was $6.2438 \mathrm{~kg}$. After the completion of intervention the mean weight was 7.9250 $\mathrm{kg}$. There was $27 \%$ improvement within the study group at $\mathrm{p}$ value $<0.001$ on applying the paired ' $\mathrm{t}$ ' test within the group. The initial mean height of the infants in the study group before starting the weaning food was 64.67 $\mathrm{cm}$. After the completion of intervention the mean height was $68.04 \mathrm{~cm}$. There was $5.52 \%$ improvement within the study group at $\mathrm{p}$ value $<0.001$ on applying the paired ' $\mathrm{t}$ ' test within the group. The initial mean head circumference (HC) of the infants in the study group before starting the weaning food was $42.79 \mathrm{~cm}$. After the completion of intervention the mean $\mathrm{HC}$ was $43.62 \mathrm{~cm}$. There was $2 \%$ improvement within the study group at $\mathrm{p}$ value $<0.001$ on applying the paired ' $t$ ' test within the group. The initial mean chest circumference (CC) of the infants in the study group before starting the weaning food was $41.53 \mathrm{~cm}$. After the completion of intervention the mean $\mathrm{CC}$ was $43.65 \mathrm{~cm}$. There was a $5.10 \%$ improvement within the study group at $p$ value $<0.001$ on 
applying the paired ' $\mathrm{t}$ ' test within the group. The initial mean mid arm circumference (MAC) of the infants in the study group before starting the weaning food was 13.70 $\mathrm{cm}$. After the completion of intervention the mean MAC was $15.08 \mathrm{~cm}$. There was a $10 \%$ improvement within the study group at $\mathrm{p}$ value $<0.001$ on applying the paired ' $\mathrm{t}$ ' test within the group. (Table 1)

The initial mean weight of the infants in the control group was $6.548 \mathrm{~kg}$. After the completion of intervention the mean weight was $8.018 \mathrm{~kg}$. There was $22 \%$ improvement within the control group at $\mathrm{p}$ value $<0.001$ on applying the paired ' $t$ ' test within the group. The initial mean height of the infants in the control group before starting the weaning food was $61.93 \mathrm{~cm}$. After the completion of intervention the mean height was $66.12 \mathrm{~cm}$. There was $6.76 \%$ improvement within the control group at $\mathrm{p}$ value $<$ 0.001 on applying the paired ' $t$ ' test within the group. The initial mean head circumference (HC) of the infants in the study group before starting the weaning food was 42.00 $\mathrm{cm}$. After the completion of intervention the mean $\mathrm{HC}$ was $44.75 \mathrm{~cm}$. There was $6.54 \%$ improvement within the control group at $p$ value $<0.001$ on applying the paired ' $t$ ' test within the group. The initial mean chest circumference (CC) of the infants in the control group before starting the weaning food was $40.56 \mathrm{~cm}$. After the completion of intervention the mean $\mathrm{CC}$ was $42.81 \mathrm{~cm}$. There was a $5.55 \%$ improvement within the control group at $\mathrm{p}$ value $<0.001$ on applying the paired ' $\mathrm{t}$ ' test within the group. The initial mean mid arm circumference (MAC) of the infants in the control group before starting the weaning food was $13.62 \mathrm{~cm}$. After the completion of intervention the mean MAC was $15.21 \mathrm{~cm}$. There was an $11.67 \%$ improvement within the control group at $\mathrm{p}$ value $<0.001$ on applying the paired ' $t$ ' test within the group. (Table 2)

On applying un-paired ' $t$ ' test between the groups, the results showed that though $\mathrm{P}$ value was $>0.05$ but comparing the mean weight of both groups- Study group 7.87 and Control group $8.10 \mathrm{~kg}$ respectively, shows that weight gain in the study group was as good as and at par with that of control group. On applying un-paired ' $t$ ' test between the groups, the results showed that $\mathrm{P}$ value was $>$ 0.05 but comparing the mean Head Circumference of both groups. Study group $45.33 \mathrm{~cm}$ and Control group 44.66 $\mathrm{cm}$ respectively, shows that Head Circumference gain in the study group was as good as and at par with that of control group. On applying un-paired ' $t$ ' test between the groups, the results showed that though $\mathrm{P}$ value was $<0.05$ but comparing the mean Chest Circumference of both groups- Study group $43.58 \mathrm{~cm}$ and Control group 42.76 $\mathrm{cm}$ respectively, shows that Chest Circumference gain in the study group was $2 \%$ over control group. On applying un-paired ' $t$ ' test between the groups, the results showed that though $\mathrm{P}$ value was $>0.05$ by comparing the mean Mid Arm Circumference of both groups. Study group $15.05 \mathrm{~cm}$ and Control group $15.26 \mathrm{~cm}$ respectively, shows that Mid Arm Circumference gain in the study group was as good as and at par with that of control group. On applying un-paired ' $t$ ' test between the groups, the results showed that though $\mathrm{P}$ value was $<0.05$ by comparing the mean Height of both groups. Study group $68.04 \mathrm{~cm}$ and Control group $66.00 \mathrm{~cm}$ respectively, shows that Height gain in the study group was $3 \%$ over control Group. (Table 3)

Post hoc analysis with Wilcoxon signed rank test was conducted with a Bonferroni correction, resulting in a significance level set at $p<0.05$. It was found that there was no statistically significant reduction in frequency of attack of disease $(Z=1.890)(P=0.59)$ in the control group. There was statistically significant improvement in sleep pattern after the study in 4 infants with no change (but not altered sleep pattern either) in the 12 infants, with 0 patients with altered sleep pattern $(\mathrm{Z}=2.000)(\mathrm{P}=$ $0.46)$. There was statistically significant improvement in Bowel pattern after the study in 6 infants, with no change (but not altered Bowel pattern either) in the 10 infants, with 0 patients with altered sleep pattern $(\mathrm{Z}=2.449)(\mathrm{P}=$ 0.14). (Table 4)

After the study was completed there was statistically significant improvement in reduction of disease attack in 3 infants, with no change in 14 infants, increase in 0 patients $(Z=1.732)(p=0.001)$. There was statistically significant improvement in sleep pattern after the study in 11 infants with no change (but not altered sleep pattern either) in the 6 infants, with 0 patients with altered sleep pattern $(Z=3.317)(P=0.001)$. There was statistically significant improvement in bowel pattern after the study in 14 infants, with no change (but not altered Bowel pattern either) in the 3 infants, with 0 patients with altered sleep pattern $(Z=3.742)(P=0.002)$. Table 5)

Despite of improvement in bowel pattern in both the groups assessed separately but while comparing both groups no significant improvement was found in study group over the control group. At $(\mathrm{Z}=.913)(\mathrm{P}=.361)$ mean rank $(\mathrm{MR}=17.42)(\mathrm{MR}=16.50)$ the improvement in the sleep pattern of study and control groups respectively was not found to be highly significant though individually in Wilcoxon sign rank test were statistically significant. There was statistically significant improvement in Attack of Disease with mean rank $(\mathrm{MR}=$ 19.58) $(M R=13.90)(Z=2.373)(p=0.18)$ of the Study and control Group respectively over control group. (Table 6)

\section{DISCUSSION}

Acharya Kashyapa has mentioned the use of Shashtika shali or Purana shali which is husk-free and well washed. Along with fine powders of Godhuma, Yava, that should be given as semi-solid porridge cooked daily adding oleaginous substances and salt. Vidanga also is added to prevent further gastrointestinal disorders. Further Acharya Kashyapa mentions that Vaidya (physician) should also take into considerations factors like Desha (Region/Placewhere child is living), Agni (Digestive Fire/Metabolism), Bala (strength), Kala (time), or whenever child is hungry, according to congeniality. Ingredients of the present weaning food are, Shali, Yava, Godhuma, Jatiphala, Ela, and Vidanga. ${ }^{11-12}$ Among them Shali, Yava, Godhuma are the main ingredients of the trial drug. Shali is Brumhana, Hridya, Balya, Ruchya and Pittagna. Godhuma is Balya, Brumhana, Hridya, Ruchiprada, Pathya, Kasaghna, Sara, Sheeta, Sandhana Krut and Vata-pittagna. Yava is Krimi Shleshmahara, Vishahara, Pushtikara, Balakara, Pittahara and Agnivardhaka. ${ }^{13}$ 
Table 1: Paired 't' test in study group

\begin{tabular}{|c|c|c|c|c|c|c|c|}
\hline Parameter & Mean BT & Mean AT & Mean difference & SD & SE mean & T value & P value \\
\hline Weight & 6.2438 & 7.9250 & -1.68125 & .28802 & .07201 & -23.349 & $<.001$ \\
\hline Height & 64.6765 & 68.0471 & -3.37059 & .65361 & .15852 & -21.262 & $<.001$ \\
\hline HC & 42.7941 & 43.6294 & -.83529 & .27143 & .06583 & -12.688 & $<.001$ \\
\hline CC & 41.5312 & 43.6562 & -2.12500 & .78528 & .19632 & -10.824 & $<.001$ \\
\hline MAC & 13.7059 & 15.0882 & -1.38235 & .37622 & .09125 & -15.149 & $<.001$ \\
\hline
\end{tabular}

Table 2: Paired ' $t$ ' test in control group

\begin{tabular}{|c|c|c|c|c|c|c|c|}
\hline Parameter & Mean BT & Mean AT & Mean difference & SD & SE mean & T value & P value \\
\hline Weight & 6.5488 & 8.0188 & -1.47000 & .38609 & .09652 & -15.230 & $<.001$ \\
\hline Height & 61.9375 & 66.1250 & -4.18750 & 1.75000 & .43750 & -9.571 & $<.001$ \\
\hline HC & 42.0000 & 44.7500 & -2.75000 & 1.03280 & .25820 & -10.651 & $<.001$ \\
\hline CC & 40.5625 & 42.8125 & -2.25000 & .73030 & .18257 & -12.324 & $<.001$ \\
\hline MAC & 13.6250 & 15.2188 & -1.59375 & .27195 & .06799 & -23.442 & $<.001$ \\
\hline
\end{tabular}

Table 3: Unpaired ' $t$ ' test in both groups

\begin{tabular}{|c|c|c|c|c|c|}
\hline \multirow{2}{*}{ Parameters } & Study group & Control group & \multirow{2}{*}{$\begin{array}{c}\text { SEM } \\
\text { Mean Difference }\end{array}$} & t & \\
\cline { 2 - 3 } & MEAN & MEAN & -.23444 & -1.182 & $>0.05$ \\
\hline WT_AT & 7.8722 & 8.1067 & .66667 & 1.345 & $>0.05$ \\
\hline HC_AT & 45.3333 & 44.6667 & .81667 & 1.390 & $<0.05$ \\
\hline CC_AT & 43.5833 & 42.7667 & -.21111 & -1.282 & $>0.05$ \\
\hline MAC_AT & 15.0556 & 15.2667 & 2.04444 & 2.943 & $<0.05$ \\
\hline HT_AT & 68.0444 & 66.0000 & & & \\
\hline
\end{tabular}

Table 4: Effect of weaning food on in control group (Wilcoxon signed rank test as post hoc test)

\begin{tabular}{|c|c|c|c|c|c|c|c|c|c|c|}
\hline & \multicolumn{3}{|c|}{ Negative ranks } & \multicolumn{3}{|c|}{ Positive ranks } & \multirow[t]{2}{*}{ Ties } & \multirow[t]{2}{*}{ Total } & \multirow[t]{2}{*}{ Z Value } & \multirow[t]{2}{*}{ P value } \\
\hline & $\mathbf{N}$ & MR & SR & $\mathbf{N}$ & MR & SR & & & & \\
\hline Disease Attacks & 1 & 4.00 & 4.00 & 6 & 4.0 & 24.00 & $9 \mathrm{c}$ & 16 & 1.890 & .059 \\
\hline Sleep pattern & 4 & 2.50 & 10.00 & 0 & .00 & .00 & $12 \mathrm{c}$ & 16 & 2.000 & .046 \\
\hline Bowel pattern & 6 & 3.50 & 21.00 & 0 & .00 & .00 & 10 & 16 & 2.449 & .014 \\
\hline
\end{tabular}

Table 5: Effect of weaning food on in study group (Wilcoxon signed rank test as post hoc test)

\begin{tabular}{|c|c|c|c|c|c|c|c|c|c|c|}
\hline \multirow{2}{*}{ Parameters } & \multicolumn{3}{|c|}{ Negative ranks } & \multicolumn{3}{|c|}{ Positive ranks } & \multirow{2}{*}{ Ties } & \multirow{2}{*}{ Total } & \multirow{2}{*}{ Z Value } & \multirow{2}{*}{ P value } \\
\cline { 2 - 11 } & N & MR & SR & N & MR & SR & & & & \\
\hline Disease Attacks & 3 & 2.00 & 6.00 & 0 & 0 & .00 & 14 & 17 & 1.732 & 0.001 \\
\hline Sleep pattern & 11 & 6.00 & 66 & 0 & .00 & .00 & 6 & 17 & 3.317 & 0.001 \\
\hline Bowel pattern & 14 & 7.50 & 105.0 & 0 & .00 & .00 & 3 & 17 & 3.742 & 0.002 \\
\hline
\end{tabular}

Table 6: Mann Whitney $U$ Test between the groups

\begin{tabular}{|c|c|c|c|c|c|c|c|}
\hline \multirow{2}{*}{ Parameters } & \multicolumn{2}{|c|}{ Study group } & \multicolumn{2}{|c|}{ Control group } & \multirow{2}{*}{ Z Value } & P value & Remark \\
\cline { 2 - 5 } & MR & SR & MR & SR & & & \\
\hline Bowel & 15.92 & 286.50 & 18.30 & 274.50 & 1.247 & .213 & NS \\
\hline Sleep & 17.42 & 313.50 & 16.50 & 247.50 & .913 & .361 & NS \\
\hline Disease attack & 19.58 & 352.50 & 13.90 & 208.50 & 2.373 & .018 & S \\
\hline
\end{tabular}

Drugs like Jatiphala and Ela are mainly Kasa Shvasaghna, Ruchya and Deepana. Vidanga is mainly Krimihara and Deepana-Pachana in nature. ${ }^{14}$

\section{CONCLUSION}

The given nutritional supplement was highly appreciated by the mothers, as the acceptance of product by the infant was very good and no untoward effects were reported. Shashtikashalyadi Churna showed better palatability than routine food in the control group. The overall result shows that the nutritional supplement in the form of Shashtikashalyadi Churna as a weaning food was effective in accelerating the growth and development of the child both in weight gain and in increase in head circumference. This may be because it provides the child extra calories, protein and essential fatty acids necessary for growth of body and brain. They compensate the gap between the required and provided nutrition (calories).

\section{ACKNOWLEDGEMENTS}

Authors greatly acknowledge the support and input given by the faulty of Department of Kaumarabhritya, SDM College of Ayurveda and Hospital, Hassan, Karnataka, India during the course of the study.

\section{REFERENCES}

1. Ghai OP, Paul V, Bagga A. Ghai Essential Pediatrics. $7^{\text {th }}$ ed. New Delhi: CBS Publishers and distributors; 2010. p. 99.

2. Arun Raj GR, Shailaja U, Prasanna N Rao. The childhood samskaras (Rites of passage) and its scientific appreciation. Ayurpharm Int J Ayur Alli Sci 2013; 2(12): 372-383.

3. Arun Raj GR, Shailaja U, Rao Prasanna N. Growth and development in children: An Ayurvedic perspective. International Journal of Ayurvedic and Herbal Medicine 2013; 3(5): 1337-1342.

4. Lekshmi MK. A study on the efficacy of priyalamajjadi yoga in the growth and development of children during complementary feeding. Kerala: University of Kerala; 2008.

5. Sachadeva HPS, Chowdhary P. Nutrition in Children Developing country concerns, Reprint ed. Delhi: BI Publications; 1994. p. 112.

6. Temesgen M. Nutritional Status of Ethiopian Weaning and Complementary Foods: A Review 2013; 2: 621.

7. Shailaja U, Rao Prasanna N, Arun Raj GR. Clinical study on the efficacy of Samvardhana ghrita orally and by matrabasti in motor 
disabilities of cerebral palsy in children. Int. J. Res. Ayurveda Pharm 2013; 4(3): 373-377. http://dx.doi.org/10.7897/22774343.04313

8. Sachadeva HPS, Chowdhary P. Nutrition in Children Developing country concerns, Reprint ed. Delhi: BI Publications; 1994. p. 109.

9. Tewari PV. Kashyapa Samhita, Reprint ed. Varanasi: Chowkhamba Vishwabharti Oriental Publications; 2008. p. 599.

10. Ghai OP, Paul K, Bagga A. Ghai Essential Pediatrics, $7^{\text {th }}$ ed. New Delhi: CBS Publishers and Distributors Pvt Ltd; 2009. p. 33.

11. Raj GRA, Shailaja U, Rao PN and Ajayan S. Review on the concept of Immunomodulation in Ayurveda with special emphasis on Prakara yoga. Int J Pharm Sci Res 2014; 5(4): 1116-23.

12. Arun Raj GR, Shailaja U, Prasanna N Rao, Ajayan S, Nivya P Thomas. Review on the contribution of Ura-Marunnu, a traditional baby care practice in southern India. The Pharma Innovation 2014; 2(11): 42-70.

13. Rahul Jain, Praveen Raghuwanshi, Satish B Patil. Yava (Barley) - A key to the life style disorders. Ayurpharm Int J Ayur Alli Sci 2013; 2(5): 138-143.

14. Sastry JLN. Illustrated Dravyaguna Vijnana. $2^{\text {nd }}$ ed. Varanasi: Chaukhambha Orientalia; 2005. p. 319.

Cite this article as:

Sharvari S Deshpande, Shailaja U, Arun Raj GR, Arya TU. Assessment of growth and development in infants with Shashtikshalyadi churna as weaning food: A clinical study. Int. J. Res. Ayurveda Pharm. 2014;5(4):439-443 http://dx.doi.org/10.7897/2277-4343.05490

Source of support: Nil, Conflict of interest: None Declared 